ISSN 1392-3196 / e-ISSN 2335-8947

Zemdirbyste-Agriculture, vol. 101, No. 2 (2014), p. 161-168

DOI 10.13080/z-a.2014.101.021

\title{
False flax (Camelina sativa L.) as an alternative source for biodiesel production
}

\author{
Danutė KARČAUSKIENE் ${ }^{1,3}$, Egle SENDŽIKIENË², Violeta MAKAREVIČIENË², \\ Ernestas ZALECKAS ${ }^{2}$, Regina REPŠIENE ${ }^{1}$, Dalia AMBRAZAITIENE ${ }^{1,3}$ \\ ${ }^{1}$ Vezžaičiai Branch, Lithuanian Research Centre for Agriculture and Forestry \\ Gargždų 29, Vèžaičiai, Klaipėda distr., Lithuania \\ E-mail: danuteo@vezaiciai.lzi.lt \\ ${ }^{2}$ Aleksandras Stulginskis University \\ Studentų 11, Akademija, Kaunas distr., Lithuania \\ ${ }^{3}$ Klaipèda University \\ H. Manto 84, Klaipėda, Lithuania
}

\begin{abstract}
The current study hypothesizes that false flax (Camelina sativa L.), as a high-value biofuel feedstock, could be grown under humid conditions of western Lithuania and that nitrogen fertilisation could influence its seed yield and oil content. The following objectives were pursued: 1) to determine the optimum nitrogen fertiliser rate for winter $\left(\mathrm{N}_{0}, \mathrm{~N}_{50}, \mathrm{~N}_{100}, \mathrm{~N}_{150}\right)$ and summer $\left(\mathrm{N}_{0}, \mathrm{~N}_{30}, \mathrm{~N}_{60}, \mathrm{~N}_{90}, \mathrm{~N}_{120}\right)$ types of false flax, 2) to estimate false flax seed oil content, its composition and feasibility to use it for the production of biodiesel fuel. The experiments were conducted in 2008-2011 at the Véžaičiai Branch of the Lithuanian Research Centre for Agriculture and Forestry. It was revealed that the highest $\left(1.28 \mathrm{t} \mathrm{ha}^{-1}\right.$, in 2010) and $\left(1.29 \mathrm{t} \mathrm{ha}^{-1}\right.$, in 2011) as well as cost-efficient summer false flax seed yield was produced having fertilised with $90 \mathrm{~kg} \mathrm{ha}^{-1}$ of nitrogen. Significantly highest $\left(1.2 \mathrm{t} \mathrm{ha}^{-1}\right.$, in 2011 and $1.6 \mathrm{t} \mathrm{ha}^{-1}$, in 2010) winter false flax seed yield was obtained having fertilised with $\mathrm{N}_{100}$. In our study, the seed oil content of summer false flax amounted to $40.3 \%$ and that of winter false flax was lower $-37.0 \%$. Nitrogen fertilisation $\left(\mathrm{N}_{150}\right.$ and $\left.\mathrm{N}_{120}\right)$ increased protein content in winter false flax seed from $22.98 \%$ to $26.97 \%$ and in summer false flax seed from $20.53 \%$ to $23.23 \%$ and did not reduce seed oil content. Methyl esters of false flax oil have a high iodine value and an especially high content of polyunsaturated linolenic acid: it reached $38.2 \%$ in winter false flax oil and $34.3 \%$ in summer false flax oil. Therefore false flax methyl esters can be used as fuel for diesel engines only in mixtures containing $40-50 \%$ of methyl esters of animal origin (used frying oil or pork lard). The most effective antioxidant Ionol BF200 (optimal dosage $-500 \mathrm{ppm}$ ) as well as the most effective depressants Wintron XC-30 (optimal dosage - 1500 ppm) and Infineum R-442 (optimal dosage - 1200 ppm) were selected for improvement of oxidation stability and cold flow properties of esters.
\end{abstract}

Key words: Camelina sativa, nitrogen fertilizers, oil composition, seed yield.

\section{Introduction}

In Lithuania, as well as across the Member States of the European Union, biodiesel fuel is produced mainly from rapeseed oil. Increasing demand for conventional feedstock to be converted to biodiesel is limited by the field area and growth potential (290.000 ha of rapeseed in Lithuania). Another problem related to the production of biodiesel is that its production involves the use of rapeseed oil suitable for food purposes. In order to minimize the adverse impact of the production of biodiesel on the food sector, it is necessary to look for alternative biofuel sources for the production of biodiesel.

False flax (Camelina sativa L.) could be one of such oilseed crops (Zubr, Matthäus, 2002). Because of the high content of unsaturated fatty oils, false flax seed oil belongs to the group of fast-drying oils. Therefore, it is used for the production of environmentally friendly polymers, varnishes and paints. Like all other vegetable oils, false flax-seed oil can be used for technical purposes, especially for biodiesel fuel production (Budin et al., 1995; Peiretti, Meineri, 2007). Therefore it is necessary to produce high false flax seed yield. Literary review shows the positive effect of nitrogenous fertilization on false flax seed yield (Ryant, 2003; Johnson et al., 2008). Research conducted in Germany showed that the highest yield $\left(2.28 \mathrm{t} \mathrm{ha}^{-1}\right)$ of summer false flax in loamy soil is produced after fertilizing with 80 and $120 \mathrm{~kg} \mathrm{ha}^{-1}$ rates of nitrogen fertilizers, at a sowing rate of 400 seeds per $\mathrm{m}^{2}$ (Agegnehu, Honermeier, 1996). Research conducted in England and France showed that the recommended rate of nitrogen fertilizers for summer false flax is $100 \mathrm{~kg} \mathrm{ha}^{-1}$, at a sowing rate of 350 seeds per $\mathrm{m}^{2}$. Some authors suggest more intensive $\left(120-130 \mathrm{~kg} \mathrm{ha}^{-1} \mathrm{~N}\right)$ use of nitrogen fertilizers (Person et al., 1999). According to studies in Canada, the seed yield of false flax was influenced by 
location (Gugel, Falk, 2006). Lo ák et al. (2011) indicates that false flax can be grown on virtually all kinds of soils, with the exception of heavy, waterlogged and acid soils and on weed-infested land. False flax is able to realize the high yield capacity only on favourable soil and growing conditions (Agegnehu, Honermeier, 1996). Compared to rapeseed, false flax is more resistant to unfavourable climatic conditions, especially high resistance against drought and low temperatures was noticed (Vollmann et al., 2007). Baranyk et al. (1995) proved that the average oil content of the seeds is over $30 \%$, although literary data indicate that it is as much as $42 \%$, including a high content of unsaturated fatty acids (Zubr, Matthäus, 2002; Abramovič, Abram, 2005; Berti et al., 2011). However, it is probable that the biodiesel fuel will fail to comply with the requirement of standard EN 14214 in respect of iodine value due to the composition of the fatty acids (high content of polyunsaturated acids) (Peiretti, Meineri, 2007). This problem can be solved by mixing false flax seed oil with other fats or oils, which have higher content of saturated fatty acids. Having summarised the controversial literature data on false flax requirements for climatic and soil conditions, and fertilizer management, we can maintain that false flax needs to be further tested for its technological properties in order to use its oil for biodiesel fuel production.

The aim of our research was to study the possibilities of producing the maximum false flax seed yield under western Lithuania's climatic conditions and using seed oil for biodiesel fuel production.

\section{Materials and methods}

Experimental site. The research was conducted in 2008-2011 at the field crop rotation of Véžaičiai Branch of Lithuanian Research Centre for Agriculture and Forestry, Western Lithuania, the eastern edge of the coastal plain $\left(55^{\circ} 43^{\prime} \mathrm{N}, 21^{\circ} 27^{\prime} \mathrm{E}\right)$.

Research object. Summer false flax (Camelina sativa L.) cv. 'Borowska' and winter false flax cv. 'Przybrodzka'.

Research conditions. Soil is moderately cultivated Dystrict Albeluvisol ( $A B d$ ), texture - morain loam, clay content $14-16 \%$ with medium content of organic carbon $(1.15 \%)$, phosphorus (115 mg kg-1) and potassium (124 mg kg-1), $\mathrm{pH} 4.5-5.0$. Climate is moderately warm and humid. The region's mean annual amount of precipitation is more than $800 \mathrm{~mm}$, about $62 \%$ of which is in warm period (between May and September) during the growing season of plants. The mean daily temperature in May is $11.2^{\circ} \mathrm{C}$, in June $-14.8^{\circ} \mathrm{C}$, in July $16.9^{\circ} \mathrm{C}$. The weather conditions for growing plants were less or more favourable, but the drought in spring in April and May (Fig. 1), during seed emergence and germination periods had a negative effect on the productivity of false flax in 2008, 2009 and 2011.

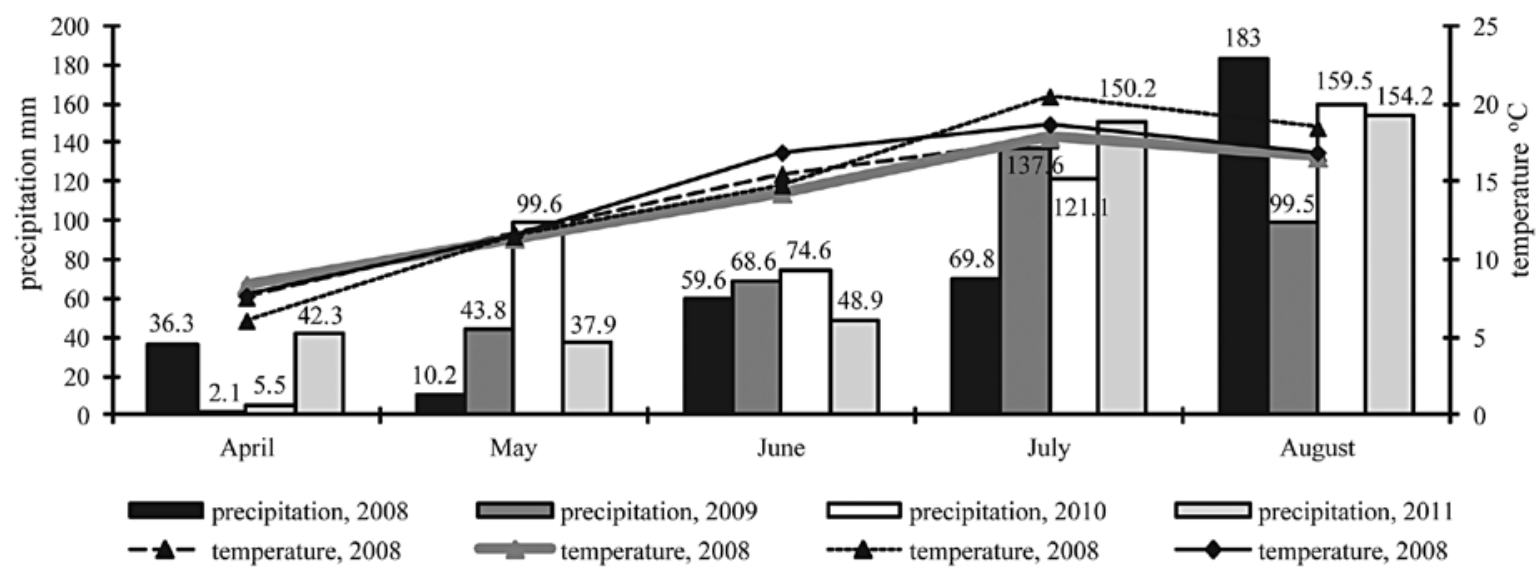

Figure 1. Climatic conditions during the false flax (Camelina sativa) vegetation period

Field trial design. Study of the effect of nitrogen (N) fertilizers on the yield of false flax was done using the scheme: $\mathrm{N}_{0}, \mathrm{~N}_{30}, \mathrm{~N}_{60}, \mathrm{~N}_{90}, \mathrm{~N}_{120}$ (for summer false flax) and $\mathrm{N}_{0}, \mathrm{~N}_{50}, \mathrm{~N}_{100}, \mathrm{~N}_{150}$ (for winter false flax). Trial design was established in a randomised bloc with four replications. The size of plots was $3.0 \times 11=33 \mathrm{~m}^{2}$. Fertilization: $60 \mathrm{~kg} \mathrm{ha}^{-1} \mathrm{P}_{2} \mathrm{O}_{5}$ (granular superphosphate $300 \mathrm{~kg} \mathrm{ha}^{-1}$ ), $60 \mathrm{~kg} \mathrm{ha}^{-1} \mathrm{~K}_{2} \mathrm{O}$ (potassium chloride $100 \mathrm{~kg} \mathrm{ha}^{-1}$ ) and 30-150 kg ha-1 $\mathrm{N}$ according to a study scheme (calcium ammonium nitrate $85-430 \mathrm{~kg} \mathrm{ha}^{-1}$ ). The fertilizers were applied before sowing and cultivated to the depth of $8-10 \mathrm{~cm}$. The highest rates $\left(90,100,120\right.$ and $\left.150 \mathrm{~kg} \mathrm{ha}^{-1}\right)$ of nitrogen fertilizer were applied in two or three times (before sowing and during vegetation). Soil tillage: in the autumn conventional ploughing at the depth of 23$25 \mathrm{~cm}$, in spring - cultivation with a combined cultivator (germinator). Pre-crop was bare fallow and winter wheat. A seed rate of $6 \mathrm{~kg} \mathrm{ha}^{-1}\left(400-500\right.$ seeds $\mathrm{m}^{-2}$, at a 1000 seed-weight of $1.2-1.3 \mathrm{~g}$ ) was sown at the $1-1.5 \mathrm{~cm}$ depth. Sowing time for summer false flax was when the soil conditions allowed tillage in early spring (8-28 April) and for winter type beginning of September. False flax was sprayed once against pests with lamdacihalotrin $\left(0.0075 \mathrm{~kg} \mathrm{ha}^{-1}\right)$. Summer false flax was harvested in mid-July and the winter type - in early August. Using a "Sampo-500" ("Sampo Rosenlew", Finland) harvester the yield was collected from every plot separately. False flax seed yield was calculated at $8 \%$ moisture content. 
The methods of false flax oil analysis. Esterification experiments were conducted at $60^{\circ} \mathrm{C}$ temperature (a lowered temperature was used as methanol boiling temperature is $64.7^{\circ} \mathrm{C}$ ). The reaction mixture was stirred at a speed of $250 \mathrm{~min}^{-1}$. Sulphuric acid was used as catalyst at various concentrations from $0.05 \%$ till $1.5 \%$. Amount of used methanol ranged between $2 \%$ and $8 \%$ of total oil content. After the reaction a separation of the fatty phase (triglycerides and fatty acid methyl esters) was performed, as well as the removal of methanol residues by distillation. The sample was treated with barium carbonate $\left(\mathrm{BaCO}_{3}\right)$ and left for settling for 10 minutes, and then the fatty phase was decanted. The acidity of the fatty phase was tested applying titrimetric method according to LST ISO 660:2009. Transesterification of false flax oil was carried out under $60^{\circ} \mathrm{C}$ temperature and mixing speed of $250 \mathrm{~min}^{-1}$. Various amounts of $\mathrm{NaOH}$ $(0.3 \%$ to $0.8 \%)$ as well as methanol $(10 \%$ to $18 \%)$ were employed to transesterify camelina oil in first (I) stage. The duration of the reaction was 1 hour. In the second (II) stage of transesterification, experiments were conducted by changing the amount of methanol (from $4 \%$ to $7 \%$ ) and sodium hydroxide (from $0.1 \%$ to $0.4 \%$ ) from the oil content, the duration of the reaction was still 1 hour. The obtained methyl esters were washed twice with $10 \%$ concentration of phosphoric acid solution (volume - 10\% of the reaction mixture). After the removal of sour water, methyl esters were washed with distilled water (volume $-10 \%$ of the reaction mixture), dried and analyzed. The quality of fatty acid methyl esters was determined according to the requirements of the standard LST EN 14214:2003 (EN 14214). The oxidation stability of fatty acid methyl esters produced was increased by applying an Ionol BF200 ("JSC Pemco Chemicals", Norway). The determination of oxidation stability was performed according to the requirements of the standard LST EN 14112:2004. The depressants Wintron XC-30 ("Biofuel Systems Group Limited", UK) and Infineum R-442 ("Infineum GmbH", UK) were used for reducing the cold filter plugging point (CFPP) of biodiesel fuel (fatty acid methyl esters). CFPP tests were performed according to the requirements of the standard DIN EN 116:1998. The volumes of the samples were $45 \mathrm{ml}$. Temperature was decreased in steps by 1 degree each time until the liquid was not able to run through the filter any more. Transesterification of animal fat and used for frying oil was carried out under $60^{\circ} \mathrm{C}$ temperature and mixing speed of $250 \mathrm{~min}^{-1}$, by methanol (18\% from fat or oil weight), using alkali catalyst $(\mathrm{NaOH})(0.9 \%$ from fat or oil weight). The procedure went through two stages. Produced methyl esters were washed twice by $10 \%$ (mass) 10\% phosphoric acid solution. After the mineral acid had been separated, methyl esters were washed by distilled water.

The research data was statistically evaluated by the analysis methods of correlation-regression using the statistical package $A N O V A$.

\section{Results and discussion}

False flax is a novel oilseed crop in Lithuania and research information on its response to nitrogen fertilizer is lacking.

Nitrogen fertilizers effect on summer and winter falseflax seed yield and its quality. Seed yield. Nitrogen (N) is the most important yield-boosting nutrient. Plant height, seed yield, oil content, total plant $\mathrm{N}$ and seed protein all responded to applied nitrogen rate (Urbaniak et al., 2008). It has been suggested that the seed yield of false flax and the magnitude of yield response to applied nitrogen can vary with soil type, its fertility and climatic conditions (Szczebiot, 2002; Rathke et al., 2006; Malhi et al., 2014). Solis et al. (2013) showed that false flax, usually regarded as a low-input crop, may respond to high $\mathrm{N}$ fertilization rates when grown in the environmental conditions that maximize seed yield potential. In these conditions, the maximum seed yield of $2.39 \mathrm{t} \mathrm{ha}^{-1}$ was obtained with the application of $300 \mathrm{~kg} \mathrm{ha}^{-1} \mathrm{~N}$. In contrast to the data of Solis et al. (2013), Polish researcher Szczebiot (2002) reported that the highest yield $\left(2.14 \mathrm{tha}^{-1}\right)$ of false flax was noted for the treatment with split nitrogen with a rate of $80 \mathrm{~kg} \mathrm{ha}^{-1}$. In the present study, the data obtained during the four-year experiment on a moderately cultivated moraine loam soil in Western Lithuania indicate that nitrogen fertilizers increased the yield of false flax summer type and of false flax winter type by $1.8-2.3$ and by $2.2-3.7$ times, respectively, in comparison to the yield obtained in unfertilized soil (Fig. 2).

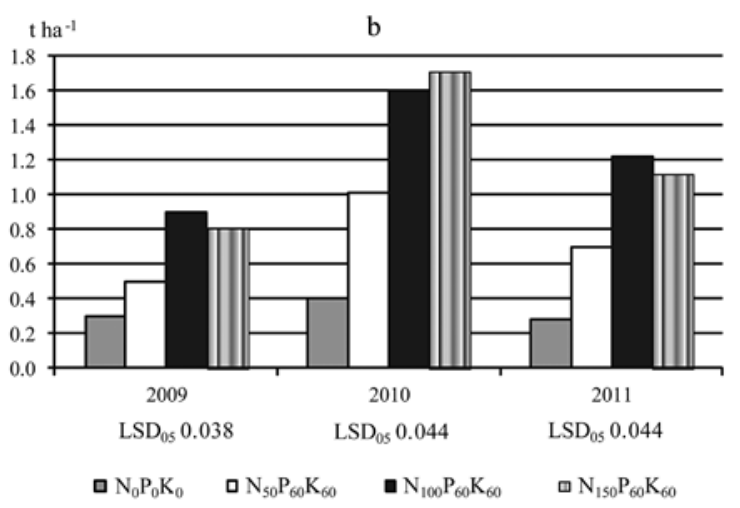

Figure 2. The effect of nitrogen fertilizers on false flax (Camelina sativa) seed yield of the summer (a) and winter (b) types

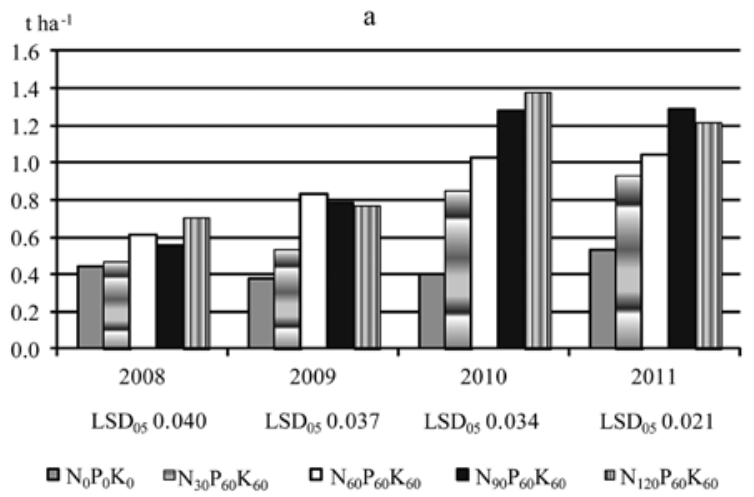


The differences in the seed yield of summer false flax between the experimental years resulted from the weather and soil conditions in all fertilization levels. Significantly the largest (1.28 and $\left.1.29 \mathrm{t} \mathrm{ha}^{-1}\right)$ and most cost-efficient summer false flax seed yield was obtained in the years (2010 and 2011) with the highest rainfall content (close to the long - term mean $334 \mathrm{~mm}$ ) during the growing season when $90 \mathrm{~kg} \mathrm{ha}^{-1}$ of nitrogen had been used. At the same fertilization level $\left(\mathrm{N}_{90}\right)$ the lowest $\left(0.56 \mathrm{t} \mathrm{ha}^{-1}\right)$ productivity of summer false flax was noted in 2008 due to worse moisture conditions. This suggests that nitrogen fertilizers were most efficient for summer false flax seed yield in the conditions of normal irrigation, while in droughty years they were less efficient. In summary, it can be maintained that in the conditions of normal irrigation in nutrient-rich, low-acidity soil, the highest seed yield was obtained having fertilized with $\mathrm{N}_{90}$ rate. Increasing of nitrogen fertilizer rate to $\mathrm{N}_{120}$ did not prove to be effective, since the yield increase at this fertilization level was as low as $6 \%$ and would not offset fertilizer costs, compared with $\mathrm{N}_{90}$ fertilization.

Wintering period is important in the winter false flax cultivation technology. Urabaniak et al. (2008) have indicated that overwinter survival largely depends on false flax variety, plant population density, and plant development before wintering. The author suggests that plants that had two or three pairs of true leaves exhibited the best over winter survival. Our data agreed with this statement. In our experiment the best over winter survival was recorded for the plants that had four pairs of true leaves, a root neck of $1.9 \mathrm{~mm}$ and leaf length of $2.2 \mathrm{~cm}$. Wintering conditions for winter false flax was favourable in 2009 and 2010, therefore the over winter survival rate amounted to $87 \%$, while in 2011 the low temperature of February had a negative effect on the wintering and the crop thinned (over winter survival rate $43 \%$ ). This had a negative impact on the seed yield. The data averaged over the 2009-2011 period showed that in the conditions of West Lithuania the seed yield of winter false flax ranged from $0.33 \mathrm{t} \mathrm{ha}^{-1}$ in the soil not applied with nitrogen fertilizer to $1.06 \mathrm{t} \mathrm{ha}^{-1}$ in the soil applied with nitrogen fertilizer. The highest seed yield $1.6 \mathrm{t} \mathrm{ha}^{-1}$ in 2010 and $1.2 \mathrm{t} \mathrm{ha}^{-1}$ in 2011 was obtained having fertilized with $\mathrm{N}_{100}$, since the plants formed 2.2 times more roots and 2.5 times more productive siliques. Biometric indicators - number of roots and siliques had the greatest impact $(r=0.96$ and $r=0.97)$ on the seed yield of both winter and summer false flax (Table 1).

Table 1. The relationship (simple correlation coefficient $r$ ) between false flax (Camelina sativa) seed yield and crop biometric parameters (averaged data of 2008-2012)

\begin{tabular}{lcccc}
\hline \multirow{2}{*}{ Biometric parameters } & \multicolumn{2}{c}{ Summer type cv. 'Borowska' } & \multicolumn{2}{c}{ Winter type cv. 'Przybrodzka' } \\
\cline { 2 - 5 } & regression equation & $r$ & regression equation & $r$ \\
\hline Branches per plant & $\mathrm{Y}=0.09682+0.08045 \mathrm{x}$ & $0.96089^{* *}$ & $\mathrm{Y}=-0.08833+0.12222 \mathrm{x}$ & $0.97388^{* *}$ \\
Number of pods per plant & $\mathrm{Y}=-0.10084+0.008 \mathrm{x}$ & $0.97379^{* *}$ & $\mathrm{Y}=-0.10084+0.008 \mathrm{x}$ & $0.97379^{* *}$ \\
Seeds per pod & $\mathrm{Y}=0.1837+0.03482 \mathrm{x}$ & 0.02963 & $\mathrm{Y}=0.1837+0.03481 \mathrm{x}$ & 0.02963 \\
\hline
\end{tabular}

$* *-P<0.01$

Seed yield quality. Nitrogen fertilization influenced oil and protein content in false flax seeds (Solis et al., 2013). In the present study, the highest protein content was obtained in the seeds of winter false flax

(26.97\%) and summer false flax (23.23\%) having fertilized with $\mathrm{N}_{150}$ and $\mathrm{N}_{120}$ rates; the oil content in them was by 3.9 and 2.7 percentage points higher compared with the seed grown without nitrogen fertilization (Table 2).

Table 2. Effect of nitrogen fertilization on summer and winter false flax (Camelina sativa) seed quality parameters

\begin{tabular}{|c|c|c|c|c|}
\hline Plant & Nitrogen fertilizer rate & $\begin{array}{c}\text { Oil content } \\
\%\end{array}$ & $\begin{array}{c}\text { Protein content } \\
\%\end{array}$ & $\begin{array}{c}\text { Moisture content } \\
\%\end{array}$ \\
\hline \multirow{5}{*}{$\begin{array}{l}\text { Summer type } \\
\text { cv. 'Borowska' }\end{array}$} & 0 & $40.5 \pm 0.50$ & $20.53 \pm 0.48$ & $6.23 \pm 0.07$ \\
\hline & 30 & $40.9 \pm 0.40$ & $21.35 \pm 0.50$ & $6.23 \pm 0.17$ \\
\hline & 60 & $40.6 \pm 0.40$ & $21.90 \pm 0.17$ & $6.23 \pm 0.17$ \\
\hline & 90 & $40.7 \pm 0.50$ & $22.91 \pm 0.13$ & $6.27 \pm 0.14$ \\
\hline & 120 & $40.9 \pm 0.30$ & $23.23 \pm 0.14$ & $6.23 \pm 0.23$ \\
\hline \multirow{4}{*}{$\begin{array}{c}\text { Winter type } \\
\text { cv. 'Przybrodzka' }\end{array}$} & 0 & $37.4 \pm 0.45$ & $22.98 \pm 0.12$ & $7.20 \pm 0.25$ \\
\hline & 50 & $38.9 \pm 0.50$ & $23.82 \pm 0.26$ & $7.24 \pm 0.10$ \\
\hline & 100 & $38.0 \pm 0.20$ & $25.82 \pm 0.45$ & $7.11 \pm 0.30$ \\
\hline & 150 & $37.9 \pm 0.20$ & $26.97 \pm 0.07$ & $7.22 \pm 0.10$ \\
\hline
\end{tabular}

The oil content in summer false flax seeds amounted to $40.9 \%$ while that of winter false flax was lower (38.9\%) (Table 2). Although many authors (Agegnehu, Honermeier, 1996; Malhi et al., 2014) have reported that nitrogen fertilization reduced oil content in false flax seeds, our research findings did not validate this proposition, since in our study the nitrogen fertilizer rates applied did not result in a significant oil content reduction.
False flax oil meets the quality requirements for biodiesel fuel under various chemical treatments (Makarevičienè, Sendžikienè, 2012).

Biodiesel production of false flax oil. The synthesis of fatty acid methyl esters (biodiesel fuel) was performed by using false flax oil with $6.8 \%$ acidity. Therefore, the transesterification of false flax was carried out under different experimental conditions by using acid 
as catalyst. In order to reduce the acidity of the false flax oil effectively, esterification experiments were conducted seeking to choose the optimum amount of methanol and a catalyst (sulphuric acid). The effectiveness of esterification was evaluated by determining acidity of reaction mixture. Effect of catalyst amount on the acidity of reaction mixture is shown in Figure 3.

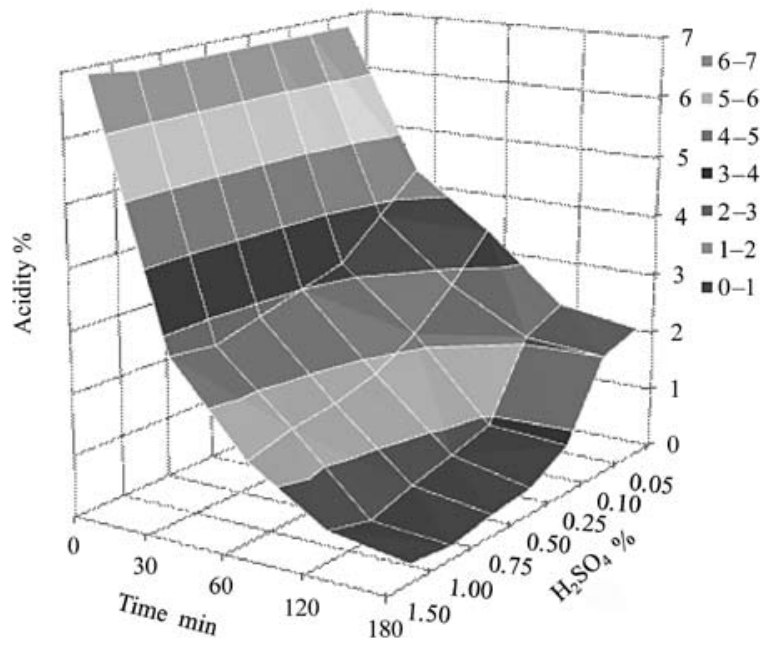

Figure 3. The effect of catalyst and methanol amount on the acidity when initial acidity is 6.8

The results clearly demonstrate that the most suitable catalyst quantity for biodiesel fuel production was between $0.75 \%$ and $1.0 \%$. When a higher concentration of the catalyst was used, the acidity of reaction mixture was slightly increased. According to the obtained results it could be predicted, that the optimum amount of methanol for esterification process is $4 \%$ to $6 \%$ of the oil weight. At these concentrations the acidity of reaction mixture decreased from $6.8 \%$ to $1.6-0.3 \%$. If the methanol content reached $4 \%$, while the sulphuric acid concentration was $0.75 \%$, the acidity of the product obtained after esterification process was $1.8 \%$. By using a higher amount of acid (1\%, amount of methanol was the same), a $0.52 \%$ acidity of the product was obtained. At higher methanol amounts $(6 \%)$ and $0.75 \%$ concentration of the catalyst (sulphuric acid) after esterification process the acidity of the oil dropped to $1.5 \%$, and if $1 \%$ concentration of the catalyst was used, the acidity was reduced to $0.3 \%$.

The effect of reaction duration on the yield of biodiesel fuel was studied at different time intervals ranging from 0.5 to 4 hours at constant temperature. It was found that it was inappropriate to prolong the duration of the esterification reaction for longer than 2 hours because it did not affect the acidity of reaction mixture. Thus, it can be concluded from the obtained results that suitable reaction duration for esterification of camelina oil was 2 hours. Transesterification of esterified false flax with methanol was performed by using alkali catalyst at different conditions. In the first (I) transesterification stage methanol content varied from $11 \%$ to $17 \%$, catalyst concentration - from $0.3 \%$ to $0.7 \%$. The obtained results are shown in Figure 4.

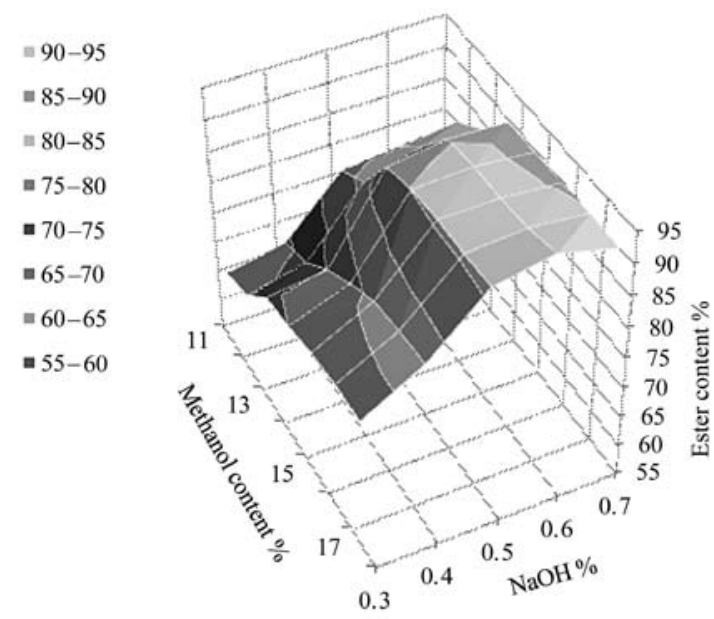

I stage

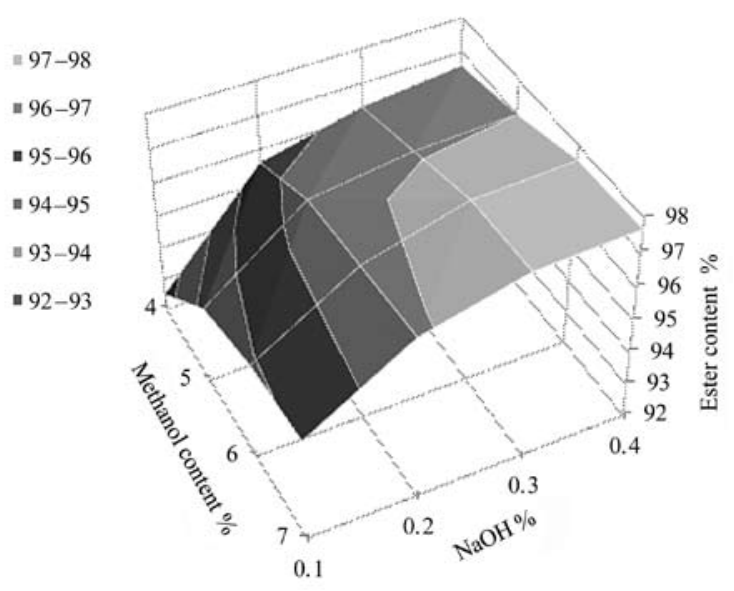

II stage

Figure 4. Influence of catalyst concentration and methanol content on false flax (Camelina sativa) oil methyl ester yield

The results show that in the first (I) transesterification stage the optimum methanol content was $14 \%$, and catalyst concentration was $0.5 \%$ from the oil weight. Under these conditions, an ester content of the product was $90.1 \%$. Further increase of the methanol content is not appropriate, because the ester content increased only till $90.5 \%$. When the $\mathrm{NaOH}$ concentration exceeded $0.6 \%$, ester quantity in the product decreased and equalled to $89.6 \%$. According to the standard requirements for biodiesel fuel, ester content in the product should be higher than $96.5 \%$. For this reason the second (II) transesterification stage was investigated. Trials by changing amount of methanol (from $4 \%$ to $7 \%$ ) and sodium hydroxide (from $0.1 \%$ to $0.4 \%$ ) were performed. The transesterification was carried out at $60^{\circ} \mathrm{C}$ temperature, stirring speed $-250 \mathrm{~min}^{-1}$, duration -1 hour.

The results showed that ester content I reaction product of at least $96.5 \%$ (as required standard) was 
reached by using $5-7 \%$ methanol and $0.2-0.4 \% \mathrm{NaOH}$. Optimal methanol content is $6 \%, \mathrm{NaOH}-0.3 \%$ (II stage). At different levels of catalyst quantity, highest yield $(97.5 \%)$ of biodiesel fuel was obtained by using $6 \%$ methanol and $0.3 \% \mathrm{NaOH}$. Various analyses for the quantification of produced biodiesel fuel were performed seeking to check its equivalence to standard. It was found out that the spring false flax (spring camelina methyl esters, SCME) and winter false flax (winter camelina methyl esters, WCME) varieties of false flax methyl esters do not pass the standard requirements for the following characteristics: iodine value (it was $164.6 \mathrm{~g} \mathrm{I}_{2}$ $100 \mathrm{~g}^{-1}$ SCME and 169.6 grams $\mathrm{I}_{2} 100 \mathrm{~g}^{-1} \mathrm{WCME}$, while the standard required max. $120 \mathrm{~g}$ of $\mathrm{I}_{2} 100 \mathrm{~g}^{-1}$ ), linolenic

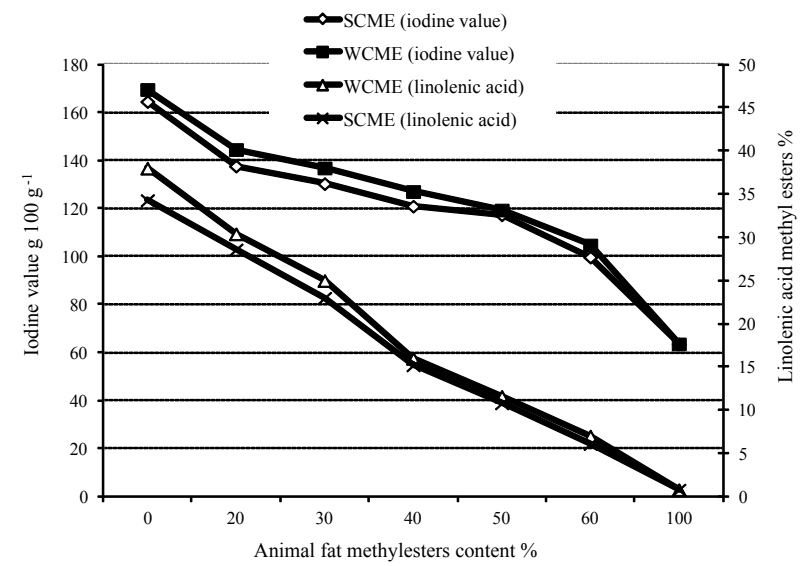

acid methyl ester content (which was $38 \%$ and $34.3 \%$ for SCME and WCME, respectively, while the standard required max. $12 \%)$, oxidation stability ( 0.43 hours, while the standard required minimum 6 hours).

The results of other research groups (Schwab et al., 1987; Tashtoush et al., 2004) show that animal fats and used cooking oil have low iodine value (50-63 $\mathrm{g} \mathrm{I}_{2}$ $100 \mathrm{~g}^{-1}$ ) and low linolenic acid methyl ester content (up to $3 \%$ ). Therefore mixtures of camelina oil methyl esters and animal fat methyl esters, as well as methyl esters produced from used frying oil were chosen for further experiments. The influence of mixtures composition on iodine value and linolenic acid methyl ester content was evaluated. Results are presented in Figure 5.

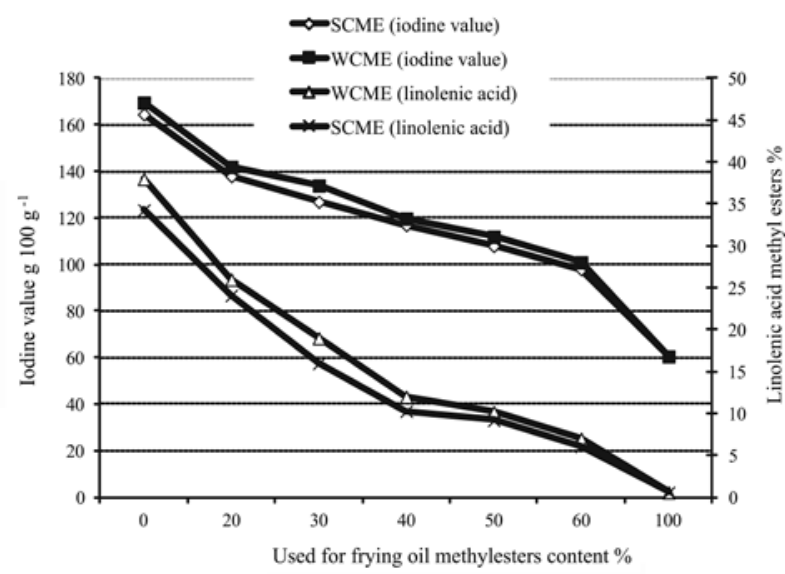

SCME - summer camelina methyl ester, WCME - winter camelina methyl ester

Figure 5. Dependence of the iodine value and linolenic acid methyl ester content on the composition of the mixtures containing false flax (Camelina sativa) oil and animal fat methylesters or methylesters produced from used frying oil

It was found that mixtures containing methyl esters of summer false flax seed oil $(50 \%)$ and pork lard (50\%) (summer camelina fatmethyl ester, SCFME), winter false flax seed oil $(50 \%)$ and pork lard (50\%) (winter camelina fat methyl ester, WCFME), spring false flax seed oil $(60 \%)$ and used frying oil (40\%) (summer camelina oil methyl ester, SCOME), and winter false flax seed oil (60\%) and used frying oil (40\%) (WCOME) meet the requirements of standard for iodine value and linolenic acid methyl ester content. It was also determined by other SCFME, WCFME, SCOME, WCOME physical and chemical characteristics as well as their compliance with the requirements of the standard. Mixtures meet other standard requirements except the CFPP and oxidation stability. The CFPP was too high, while their oxidation stability was too low. Oxidation stability is expressed by means of the induction period, which should be not less than 6 hours at temperature of $110^{\circ} \mathrm{C}$, according to the requirements of the standard for biodiesel fuel. The oxidation stability of fatty acid methyl esters can be enhanced by introducing special additives. The possibility to enhance the oxidation stability of ester mixtures by applying the industrial antioxidant Ionol BF200 was studied. For this purpose, various amounts of the oxidant were added to esters and its influence on the induction period of the ester mixes was evaluated (Fig. 6).

The obtained results showed that the minimum dosage of the antioxidant Ionol BF200, which ensures the oxidation stability of fatty acid methyl esters (SCFME, WCFME, SCOME and WCOME) was $500 \mathrm{ppm}$. The CFPP of diesel fuel used during the summer period should be not higher than $-5^{\circ} \mathrm{C}$, and that of diesel used during the winter period should be not higher than $-32^{\circ} \mathrm{C}$ (LST EN 590:2014). The CFPP of the produced fatty acid methyl esters were: $+6^{\circ} \mathrm{C}$ of SCFME, $+4.6^{\circ} \mathrm{C}$ of WCFME, $+0.8^{\circ} \mathrm{C}$ of SCOME and $+1.4^{\circ} \mathrm{C}$ of WCOME. The industrial depressants Wintron XC-30 and Infineum R-442 were applied in order to reduce the CFPP. From the obtained results (data not shown) it can be concluded that it was difficult to reduce the CFPP of those esters which contain animal fat because most depressants which reduce the CFPP are designed for fatty acid methyl esters of rapeseed oil. Even very high concentrations (up to $25.000 \mathrm{ppm}$ ) of depressants reduce the CFPP only to $2.1-3^{\circ} \mathrm{C}$ in case of SCFME and WCFME, respectively. The CFPP of fatty acid methyl esters of rapeseed oil and used frying oil is reduced to the level meeting the requirements of the standard by adding $1.500 \mathrm{ppm}$ of Wintron or $1.200 \mathrm{ppm}$ of Infinerum. 


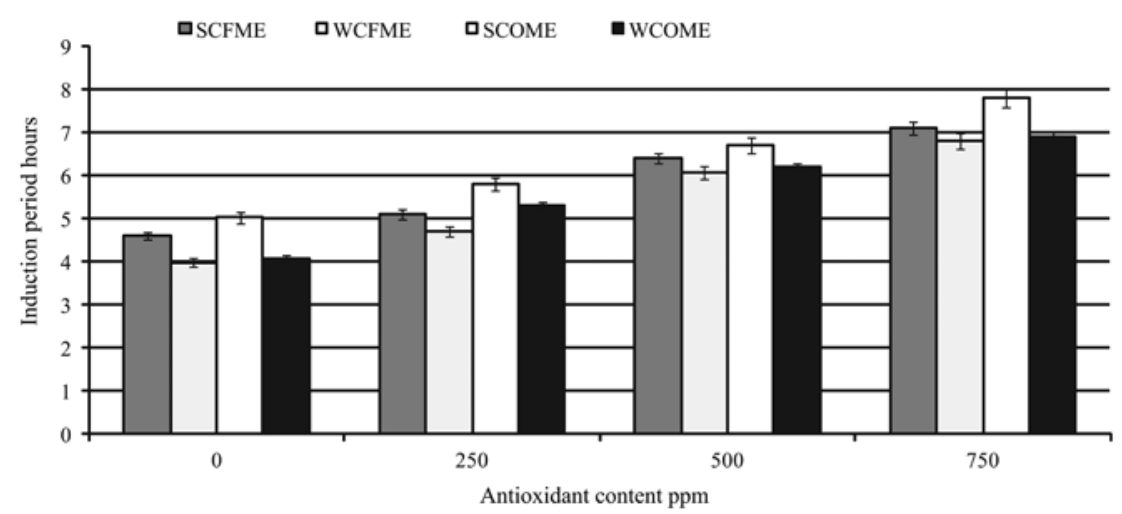

SCFME - summer false flax seed oil (50\%) and pork lard (50\%) methyl ester, WCFME - winter false flax seed oil (50\%) and pork lard (50\%) methyl ester, SCOME - spring false flax seed oil (60\%) and used frying oil (40\%) oil methyl ester, WCOME - winter false flax seed oil $(60 \%)$ and used frying oil (40\%) oil methyl ester

Figure 6. Dependence of the induction period on the concentration of antioxidant Ionol BF200

\section{Conclusions}

1. Nitrogen fertilizers increased the yield of summer and winter false flax (Camelina sativa L.) by 1.8-2.3 and by 2.2-3.7 times, respectively, in comparison to the yield obtained in unfertilized soil. The highest $\left(1.28-1.29 \mathrm{t} \mathrm{ha}^{-1}\right)$ and most cost-efficient summer false flax seed yield was obtained when $90 \mathrm{~kg} \mathrm{ha}^{-1}$ of nitrogen had been used. The optimal nitrogen rate for winter false flax was $100 \mathrm{~kg} \mathrm{ha}^{-1}$.

2. The oil and protein content in false flax seed depended on the seasonal type (winter or spring) and nitrogen fertilization. The oil content of summer false flax seeds amounted to $40.9 \%$ while that of winter false flax seed was lower (38.9\%). Nitrogen fertilization $\left(\mathrm{N}_{150}\right.$ and $\mathrm{N}_{120}$ ) increased protein content in winter false flax type from $22.98 \%$ to $26.97 \%$ and in the summer false flax from $20.53 \%$ to $23.23 \%$ and did not reduce seed oil content.

3. The highest yield of false flax methyl esters $(97.5 \%)$ was obtained when $6 \%$ methanol and $0.3 \%$ $\mathrm{NaOH}$ were used for oil transesterification. The methyl esters of summer and winter false flax did not meet the standard requirements for the following characteristics: iodine value (it was $164.6-169.6 \mathrm{~g} \mathrm{I}_{2} 100 \mathrm{~g}^{-1}$ while the standard required max. $120 \mathrm{~g}$ of $\left.\mathrm{I}_{2} 100 \mathrm{~g}^{-1}\right)$, linolenic acid methyl ester content (which was $34.3-38 \%$, while the standard required max. 12\%), oxidation stability (it was 0.43 hours, while the standard required minimum 6 hours).

4. Mixtures containing methyl esters of summer and winter false flax seed oil $(50 \%)$ and pork lard (50\%) as well as both types' seed oil (60\%) and frying oil (40\%) me the requirements of the standard for iodine value and linolenic acid methyl ester content.

5. It was possible to enhance the oxidation stability of ester mixtures by applying industrial antioxidant Ionol BF200 (optimal dosage - 500 ppm). Cold flow properties of esters mixtures were improved by addition of depressants Wintron XC-30 (optimal dosage $-1500 \mathrm{ppm}$ ) and Infineum R-442 (optimal dosage $-1200 \mathrm{ppm})$.

\section{Acknowledgments}

The paper presents research findings obtained through the long-term research programme "Biopotential and quality of plants for multifunctional use", implemented by Lithuanian Research Centre for Agriculture and Forestry.

Received 17042013

Accepted 24032014

\section{References}

Abramovič H., Abram V. 2005. Physico-chemical properties, composition and oxidative stability of Camelina sativa oil. Food Technology and Biotechnology, 43 (1): 63-70

Agegnehu M., Honermeier B. 1996. Effects of seeding rates and nitrogen fertilization on seed yield, seed quality and yield components of false flax (Camelina sativa Crtz.). Die Bodenkultur, 48 (1): 2-20

Baranyk P., Zeleny V., Zukalova H., Horejs P. 1995. Olejnatost vybranych druhu alternativnnich olejnin. Rostlinna vyroba, 41: 433-438

Berti M., Wilckens R., Fischer S., Solis A., Johnson B. 2011. Seeding date influence on camelina seed yield, yield components, and oil content in Chile. Industrial Crops and Products, 34: $1358-1365$ http://dx.doi.org/10.1016/j.indcrop.2010.12.008

Budin J. T., Breene W. M., Putnam D. H. 1995. Some compositional properties of camelina (Camelina sativa L. Crantz) seeds and oils. Journal of the American Oil Chemist' Society, 72: 309-315

DIN EN 116:1998. Diesel and domestic heating fuels. Determination of cold filter plugging point

Gugel R. K., Falk K. C. 2006. Agronomic and seed quality evaluation of Camelina sativa in western Canada. Canadian Journal of Plant Science. 86 (4): 1047-1058 http://dx.doi.org/10.4141/P04-081

Johnson E., Vera C., Klein-Gebbinck H. 2008. Agronomy of Camelina sativa. Western applied research corporation, CARP-SCDC Project, p. 56-95

Lošák T., Hlušek J., Martinec J., Vollmannn J., Peterka J., Filipčík R., Varga L., Ducsay L., Martensson A. 2011. Effect of combined nitrogen and sulphur fertilisation on yield and qualitative parameters of Camelina sativa (L.) Crtz. (false flax). Acta Agriculture Scandinavica: Section B, 61: 313-321

LST EN 590:2014. Automotive fuels-diesel requirements and test methods

LST EN 14214:2003. Automotive fuels. Fatty acid methyl esters (FAME) for diesel engines. Requirements and test methods 
LST EN 14112:2004. Fat and oil derivatives Fatty Acid Methyl Esters (FAME). Determination of oxidation stability (accelerated oxidation test)

LST ISO 660:2009. Animal and vegetable fats and oils. Determination of acid value and acidity

Makarevičienė V., Sendžikienė E. 2012. Life cycle parameters and biological degradation of biodiesel fuel produced by used Camelina sativa oil. Žemès ūkio mokslai, 19 (3), p. 161-167 (in Lithuanian)

Malhi S. S., Johnson E. N., Hall L. M., May W. E., Phelps S., Nybo B. 2014. Effect of nitrogen fertilizer application on seed yield, $\mathrm{N}$ uptake, and seed quality of Camelina sativa. Canadian Journal of Soil Science, 94 (1): 35-47 http://dx.doi.org/10.4141/cjss2012-086

Peiretti P. G., Meineri G. 2007. Fatty acids, chemical composition and organic matter digestibility of seeds and vegetative parts of false flax (Camelina sativa L.) after different lengths of growth. Animal Feed Science and Technology, 133 (3-4): 341-350 http://dx.doi.org/10.1016/j.anifeedsci.2006.05.001

Person N., Walker K., Barrow A. 1999. Camelina sativa in the $\mathrm{UK}$ : protection and production of combinable break crops. Aspects of Applied Biology, 56: 249-255

Rathke G. W., Behrens T., Diepenbroch W. 2006. Integrated nitrogen management strategies to improve seed yield, oil content and nitrogen efficiency of winter oilseed rape (Brasica napus L.): a review. Agriculture, Ecosystems and Environment. 117: 80-108 http://dx.doi.org/10.1016/j.agee.2006.04.006

Ryant P. 2003. Nutrition and fertilization of alternative oil plants for non-food purposes. Zemedelska, 1: 32-38
Schwab A. W., Bagby M. O., Freedmann B. 1987. Preparation and properties of diesel fuel from vegetable oils. Fuel, 66: 1372-1378

http://dx.doi.org/10.1016/0016-2361(87)90184-0

Solis A., Vidal I., Paulino L., Johnson B., Berti M. 2013. Camelina seed yield response to nitrogen, sulphur and phosphorus fertilizer in South Central Chile. Industrial Crops and Products. 44. v. 132-138 http://dx.doi.org/10.1016/j.indcrop.2012.11.005

Szczebiot M. 2002. Effect of mineral fertilization on yielding of spring false flax and crambe. Rosliny Oleiste, 23 (1): $141-150$

Tashtoush G., Al-Widyan M. I., Al-Jarrah M. M. 2004. Experimental study on evaluation and optimization of conversion of waste animal fat into biodiesel. Energy Conversion and Management. 45: 2697-2711 http://dx.doi.org/10.1016/j.enconman.2003.12.009

Urbaniak S., Caldwell C., Zheljazkov V., Lada R., Luan L. 2008. The effect of cultivar and applied nitrogen on the performance of Camelina sativa L. in the Maritime Provinces of Canada. Canadian Journal of Plant Sciences, 88 (1), p. 111-119 http://dx.doi.org/10.4141/CJPS07115

Vollmann J., Moritz T., Kargl C., Baumgartner S., Wagentristl H. 2007. Agronomic evaluation of camelina genotypes selected for seed quality characteristics. Industrial Crops and Products. 26 (3): 270-277 http://dx.doi.org/10.1016/j.indcrop.2007.03.017

Zubr J., Matthäus B. 2002. Effects of growth conditions on fatty acids and tocopherols in Camelina sativa oil. Industrial Crops and Products, 15 (2): 155-162 http://dx.doi.org/10.1016/S0926-6690(01)00106-6

ISSN 1392-3196 / e-ISSN 2335-8947

Zemdirbyste-Agriculture, vol. 101, No. 2 (2014), p. 161-168

DOI $10.13080 /$ z-a.2014.101.021

\title{
Sẻjamoji judra (Camelina sativa L.) - alternatyvus išteklius biodyzelino gamybai
}

\author{
D. Karčauskienè $\dot{e}^{1,3}$, E. Sendžikienè ${ }^{2}$, V. Makarevičienè ${ }^{2}$, E. Zaleckas ${ }^{2}$, R. Repšienè ${ }^{1}$, \\ D. Ambrazaitiené $\dot{1}^{1,3}$ \\ ${ }^{1}$ Lietuvos agrarinių ir miškų mokslų centro Vėžaičių filialas \\ ${ }^{2}$ Aleksandro Stulginskio universitetas \\ ${ }^{3}$ Klaipedos universitetas
}

\section{Santrauka}

Tyrimų hipoteż - sẻjamosios judros gali būti auginamos kaip didelès vertės biokuro šaltinis drègnomis Vakarų Lietuvos klimato sąlygomis, o azoto trąšos gali turèti įtakos jų sẻklų derliui ir aliejingumui. Uždaviniai: 1) nustatyti optimalią azoto trąšų normą žieminès $\left(\mathrm{N}_{0}, \mathrm{~N}_{50}, \mathrm{~N}_{100}, \mathrm{~N}_{150}\right)$ ir vasarinès $\left(\mathrm{N}_{0}, \mathrm{~N}_{30}, \mathrm{~N}_{60}, \mathrm{~N}_{90}, \mathrm{~N}_{120}\right)$ formų sèjamujų judrų sèklų derliui, 2) įvertinti séjamųjų judrų aliejingumą, aliejaus sudètị ir galimybę ji naudoti biodyzelino gamybai. 2008-2011 m. LAMMC Vèžaičių filiale atlikti tyrimai parodè, kad didžiausias $\left(1,28 \mathrm{t} \mathrm{ha}^{-1} 2010\right.$ bei $1,29 \mathrm{t} \mathrm{ha}^{-1}$ 2011) ir ekonomiškai apsimokantis vasarinès formos judrų sèklų derlius buvo gautas patręšus $90 \mathrm{~kg} \mathrm{ha}^{-1}$ azoto trąšu . Esmingai didžiausias žieminès formos judru sèklų derlius $\left(1,2 \mathrm{t} \mathrm{ha}^{-1} 2011\right.$ ir $\left.1,6 \mathrm{t} \mathrm{ha}^{-1} 2010\right)$ gautas patręšus $\mathrm{N}_{100}$. Judrų sẻklose esančio aliejaus kiekio tyrimų rezultatai parodè, kad vasarinès formos judrų sẻklose yra 40,3 $\%$ aliejaus, o žieminès formos judrų sèklose - tik 37,0 \%. Tręšimas azoto trąšomis $\left(\mathrm{N}_{150}\right.$ ir $\left.\mathrm{N}_{120}\right)$ proteinų kiekị žieminès formos judrų sėklose padidino nuo 22,98 iki $26,97 \%$, vasarinès - nuo 20,53 iki 23,23 \% ir nemažino sėklų aliejingumo. Judrų aliejaus metilesteriai pasižymi dideliu jodo skaičiumi ir linoleno rūgšties metilesterių kiekiu, kuris žieminès formos judru aliejuje siekè 38,2 \%, vasarinès formos $-34,3 \%$. Taigi, kaip dyzeliniu variklių degalai judrų aliejaus metilesteriai gali būti naudojami tik mišiniuose, kurių sudètyje yra ir 40-50\% gyvūninès kilmès (kepti naudoto aliejaus arba kiaulinių riebalų) metilesterių. Didinant esterių atsparumą oksidacijai ir gerinant žematemperatūrines savybes, efektyviausias buvo antioksidantas Ionol BF200 (optimali dozè - 500 ppm) ir depresantai Wintron XC-30 (1500 ppm) bei Infineum R-442 (1200 ppm).

Reikšminiai žodžiai: aliejaus sudètis, azoto trąšos, Camelina sativa, sėklų derlius. 